\title{
AN EXERGY COST ANALYSIS OF A COGENERATION PLANT
}

\begin{abstract}
L. P. Gonçalves, ABSTRACT
and F. R. P. Arrieta

Pontifícia Universidade Católica de Minas

Gerais

Programa de Pós-Graduação em Engenharia

Mecânica

Av. Dom José Gaspar, 500, Belo Horizonte,

Minas Gerais, Brasil

leandroengmecatronica@hotmail.com

The exergy analysis, including the calculation of the unit exergetic cost of all flows of the cogeneration plant, was the main purpose of the thermoeconomic analysis of the STAG (STeam And Gas) combined cycle CHP (Combined Heat and Power) plant. The combined cycle cogeneration plant is composed of a GE10 gas turbine $(11250 \mathrm{~kW})$ coupled with a HRSG (Heat Recovery Steam Generator) and a condensing extraction steam turbine. The GateCycle ${ }^{\mathrm{TM}}$ Software was used for the modeling and simulation of the combined cycle CHP plant thermal scheme, and calculation of the thermodynamic properties of each flow (Mass Flow, Pressure, Temperature, Enthalpy). The entropy values for water and steam were obtained from the Steam Tab software while the entropy and exergy of the exhaust gases were calculated as instructed by. For the calculation of the unit exergetic cost was used the neguentropy and Structural Theory of Thermoeconomic. The GateCycle ${ }^{\mathrm{TM}}$ calculations results were exported to an Excel sheet to carry out the exergy analysis and the unit exergetic cost calculations with the thermoeconomic model that was created for matrix inversion solution. Several simulations were performed varying separately five important parameters: the Steam turbine exhaust pressure, the evaporator pinch point temperature, the steam turbine inlet temperature, Rankine cycle operating pressure and the stack gas temperature to determine their impact in the recovery cycle heat exchangers transfer area, power generation and unit exergetic cost.
\end{abstract}

Keywords: Cogeneration, Exergy, Neguentropy, Unit exergetic cost.

\section{INTRODUCTION}

The relentless rise in energy demand for economic development and concern for the preservation of the environment are making essential that energy systems become more efficient. The design of a thermal system is limited by economic aspects before reaching the thermodynamic limit, since the most efficient systems tend to require higher initial investments, it is necessary therefore to find a balance between efficiency and cost. According to Santos (2009), for cogeneration (CHP), which is one of the possible ways to increase the efficiency of thermal systems, heat and power allocation costs techniques are required to improve the design of the thermal system. A method of cost allocation that has been used in recent times is the Thermoeconomics from the use of exergy and neguentropy. The latter is considered in this work and has been widely used in thermal cycling with a steam condenser equipment (dissipative) and / or a recovery boiler (waste exhaust): absorption (Misra et al., 2002) or compression (Accadia and Rossi., 1998) refrigeration, steam thermal power plant (Zhang et al., 2006, 2007), cogeneration with internal combustion engine applied to refrigeration (Cardona and Piacentino, 2006, 2007) and combined cycles (Valero et al . 2002; Modesto and Nebra, 2006; Erlach et al., 1999, Kwak et al., 2003).

\section{METHODOLOGY}

Initially, it was proposed a combined cycle CHP plant for steam and electricity generation consisting of a gas turbine and a Rankine cycle with a heat recovery boiler. From the information of operation of the GE10 gas turbine of $11250 \mathrm{~kW}$, obtained through the catalog Thermal Power Generation (Bolland, 2008) were performed 40 simulations of the proposed thermal scheme of the plant using the software Gate Cycle $^{\mathrm{TM}}$ from the variation of the parameters described in Table 1 and observed the changes in the steam cycle of the combined cycle plant.

Table1. Selected range for parametric studies.

\begin{tabular}{|l|c|}
\hline \multicolumn{1}{|c|}{ Parameter } & Range \\
\hline Steam turbine exhaust pressure & 5 to $15 \mathrm{kPa}$ \\
\hline Evaporator Pinch Point temperature & 5 to $25^{\circ} \mathrm{C}$ \\
\hline Steam turbine inlet temperature & 300 to $475^{\circ} \mathrm{C}$ \\
\hline Rankine Cycle operating pressure & 1 to $9 \mathrm{MPa}$ \\
\hline Stack gas temperature & 160 to $240^{\circ} \mathrm{C}$ \\
\hline
\end{tabular}

The thermodynamic properties of the flows were taken from the report of the Gate Cycle ${ }^{\mathrm{TM}}$ software. The entropy values for water and steam were obtained from the Steam Tab software (Chemical Logic, 2011), while the entropy and exergy of the exhaust gases were calculated as instructed by Lozano and Valero (1986). Then, this study followed the Structural Theory of Cost Exergy 
through which we obtained the diagram of the production structure for the proposed plant and the equations that describe the costs, making the costs matrix and the calculation of unit exergetic cost of each Component using an Excel calculation sheet for each simulation. Were also collected the values of the power produced in the thermal engines, the total power output and the heat transfer surfaces of all heat exchangers.

This study considered that both the air and exhaust gases have an ideal gas behavior, all equipment except the combustor, heat exchangers and cooling tower were considered adiabatic. Moreover, were also dismissed the transformer losses in the electric substation and the pressure losses in pipes and in the recovery boiler.

\section{Description of the Cycle}

The object of this work is a combined cycle CHP plant with a gas turbine, heat recovery boiler and Rankine cycle represented in Fig. 1. In this figure is shown the gas turbine split into compressor, combustor and turbine, and the recovery boiler composed by a superheater, an evaporator and an economizer, the steam turbo-generator, condenser, the boiler feed water pump, and the cooling tower water pump.

The operating system starts with the aspiration of atmospheric air in the compressor, which send it to the combustor where the combustion reaction occurs with the fuel and the air admitted. Then the exhaust gases pass through the turbine producing shaft work for the compressor and the electric generator, where electricity is produced. The exhaust gases after leaving the turbine, transfer energy in the recovery boiler by heat exchange in the superheater, evaporator and economizer which permits transform water in steam. The produced steam is admitted in the turbo generator to produce electricity. The steam turbine exhaust steam is then sent to the condenser to be cooled and close the Rankine cycle. For the condensation is used a cooling tower system with a cooling water pump.

To perform the simulations in the design point using the Gate Cycle $^{\mathrm{TM}}$ software were assumed the values shown in Tab. 2. Theory of Structural Exergy Costs was drawn up a diagram representing the production structure illustrated by Fig. 2 .

The parametric study of the variables in the range described in Tab. 1 aimed to modify the operating parameters of the recovery boiler, to note its impact on the heat transfer equipment, the exergy flows of the plant and in its unit exergetic cost.

\section{RESULTS AND DISCUSSION}

For each simulation were obtained the thermodynamic properties of the flows of the system, as well as the surface heat transfer for all heat exchangers, its investment cost and the unit exergetic cost flows. Referring to Fig. 3, it is possible to observe that raising the steam turbine exhaust pressure there is a reduction in the condenser surface heat transfer, due to a reduction in the thermal load of the equipment, such reduction being most evident up to $7 \mathrm{kPa}$. However, it can also observe a reduction in total and net power produced by steam turbine due to the diminishing in the enthalpy expansion, which also cause an increase in the unit exergetic cost of the produced power.

Table 2. Parameters assumed for the CHP combined cycle simulation.

\begin{tabular}{|l|c|}
\hline Ambient parameters & $15^{\circ} \mathrm{C}$ \\
\hline Ambient air temperature & $101.32 \mathrm{kPa}$ \\
\hline Atmospheric pressure & $60 \%$ \\
\hline Relative humidity (\%) & $90 \%$ \\
\hline Fuel composition & $7 \%$ \\
\hline $\mathrm{CH}_{4}(\%)$ & $3 \%$ \\
\hline $\mathrm{C}_{2} \mathrm{H}_{6}(\%)$ & $15{ }^{\circ} \mathrm{C}$ \\
\hline $\mathrm{C}_{3} \mathrm{H}_{8}(\%)$ & $0.7286 \mathrm{~kg} / \mathrm{s}$ \\
\hline Fuel temperature & $47 \mathrm{~kg} / \mathrm{s}$ \\
\hline Operating parameters of the gas turbine cycle \\
\hline Fuel mass flow & 15.6 \\
\hline Compressor inlet air mass flow & $72 \%$ \\
\hline Compressor pressure ratio & $11.25 \mathrm{MW}$ \\
\hline Compressor isentropic efficiency & $99 \%$ \\
\hline Gas turbine power output & $96 \%$ \\
\hline Combustion efficiency & $95 \%$ \\
\hline Generator electrical efficiency & $104.5 \mathrm{kPa}$ \\
\hline Reducer mechanical efficiency & $88 \%$ \\
\hline Operating parameters of the Rankine cycle \\
\hline Condenser operating pressure & $85 \%$ \\
\hline Steam turbine generator isentropic & $15.56{ }^{\circ} \mathrm{C}$ \\
\hline Pumps isentropic efficiency & $103.42 \mathrm{kPa}$ \\
\hline Makeup water temperature
\end{tabular}

Figure 4 depicts the behavior of the cycle caused by the variation of the pinch point temperature in the heat recovery boiler. It can be observed a substantial reduction in surface of heat transfer in the evaporator when increase the pinch point temperature, which represents a substantial savings in investment cost. In addition, until $17^{\circ} \mathrm{C}$ of pinch point was not observed a significant reduction in the power produced by steam turbine and in the total power output, by increasing the rate of heat transfer in the evaporator due to a higher temperature difference between the steam and the gas at the evaporator outlet. The reduction in turbine power generation occurred from $17{ }^{\circ} \mathrm{C}$, where also notes that the unit exergetic cost suffers a small increase due to the reduction in the steam temperature at the turbine inlet.

In Figure 5 is possible to observe how increases the superheater heat transfer area while the steam turbine inlet temperature rises. The increase of the heat transfer is small until $375^{\circ} \mathrm{C}$, which is important from the economic point of view, because it is 


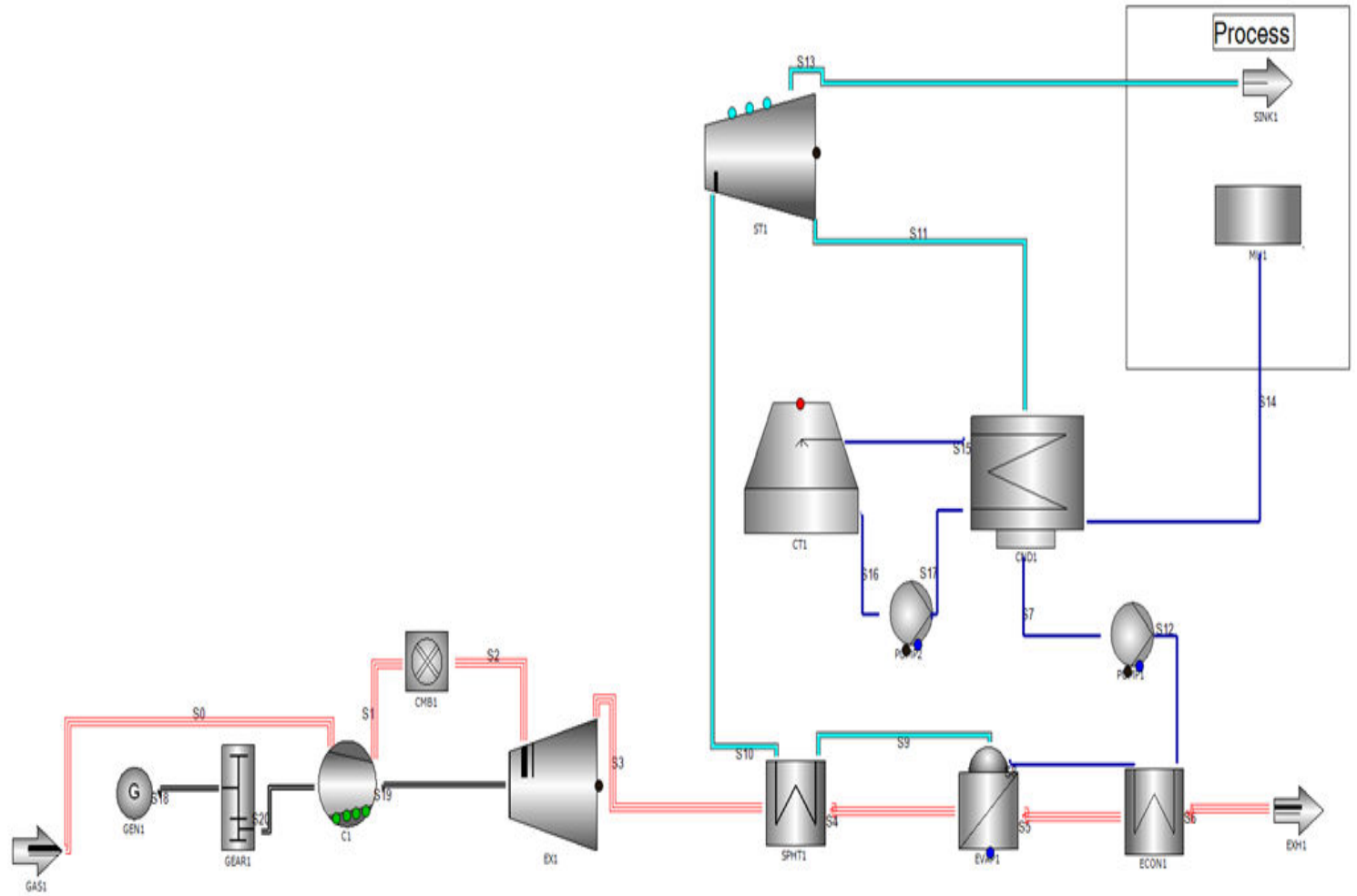

Figure 1. Thermal scheme of the CHP combined cycle plant.

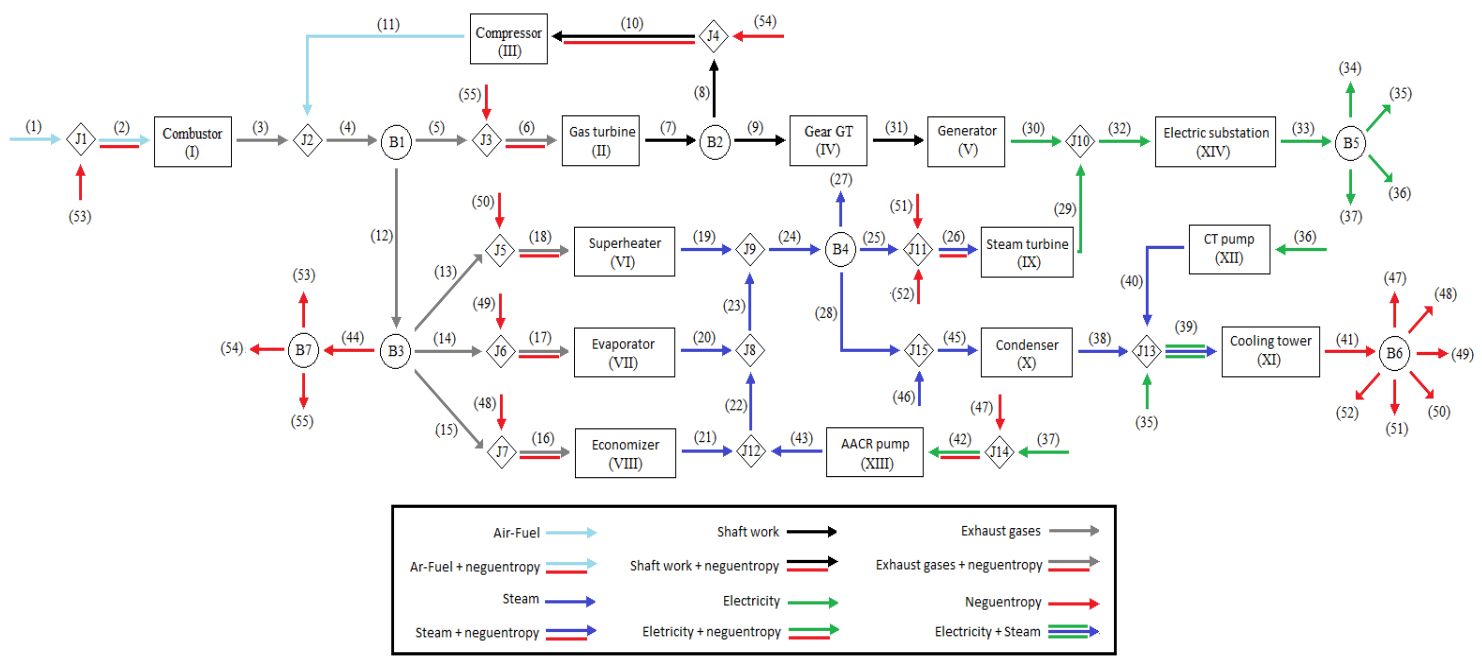

Figure 2. Productive structure.

observe an increase in the power generation and a reduction in the unit exergetic cost cause by the rise in the thermal efficiency due by the steam superheating. Higher steam turbine inlet temperature require special material for durability and reliability, increasing the costs of the generated electricity, which are interesting mainly in units with high power generation capacity.

The increase in Rankine cycle operating pressure requires largest surface of heat transfer in the superheater to maintain constant the steam turbine inlet temperature, as it is shown in Fig. 6, and rise the steam turbine generated power with reduction in the unit exergetic cost. It is observed that this behavior is more pronounced for the power and unit exergetic cost less than $5 \mathrm{MPa}$, higher pressures had no significant increases in generated power or significant reductions in the unit exergetic cost although the rise of the superheater heat transfer area remains constant, which shows the existence of a range of values in 
which is interesting to define the Rankine Cycle operating parameters for given power generation capacity.

Low stack gas temperature in the heat recovery boiler for a single pressure level configuration, as described in Fig. 7, requires a larger area of the superheater to raise the rate of heat transfer to the

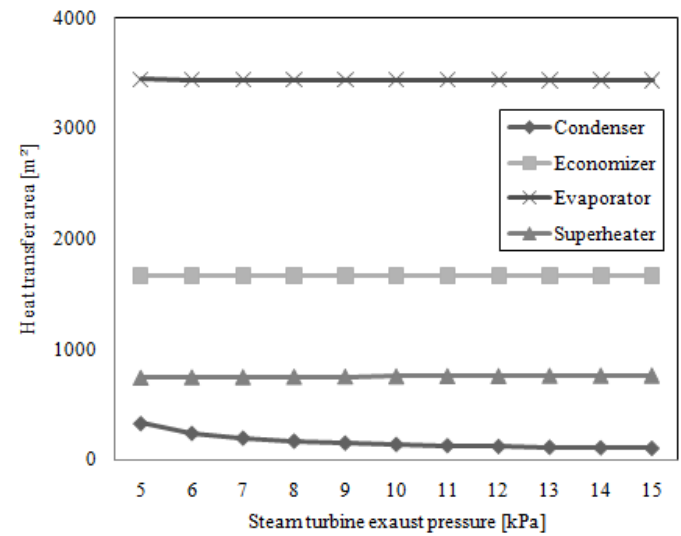

(a)
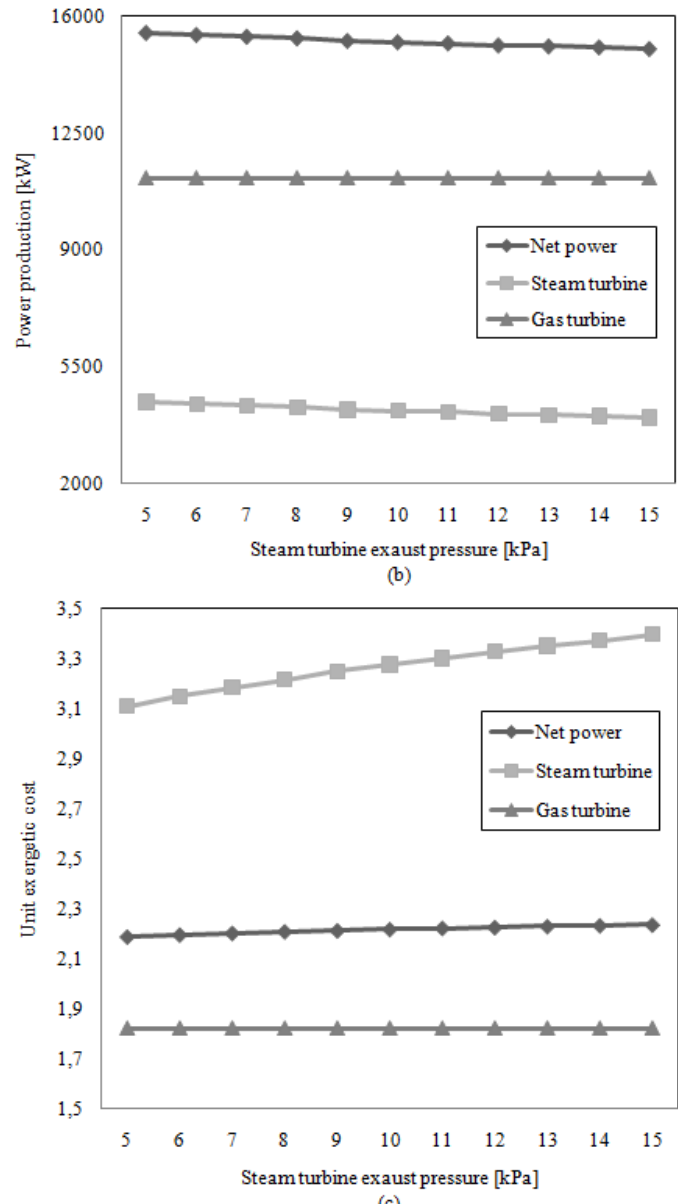

Figure 3. Impact of the increase in the steam turbine exhaust pressure in (a) the heat transfer area, (b) power production and (c) unit exergetic cost.

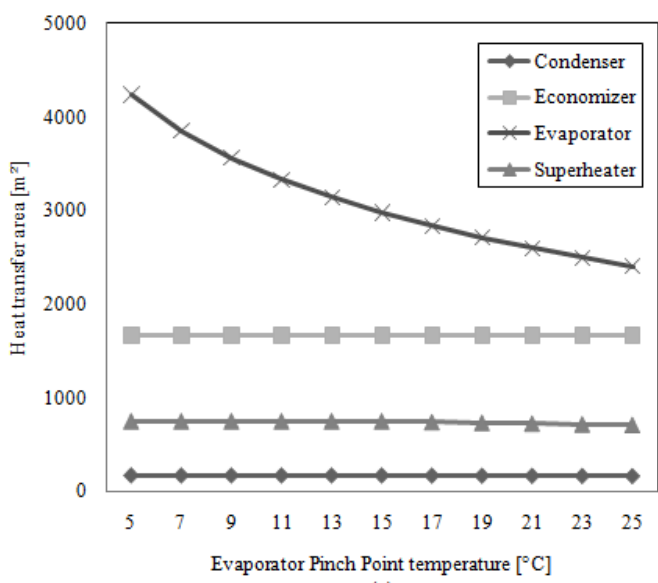

(a)

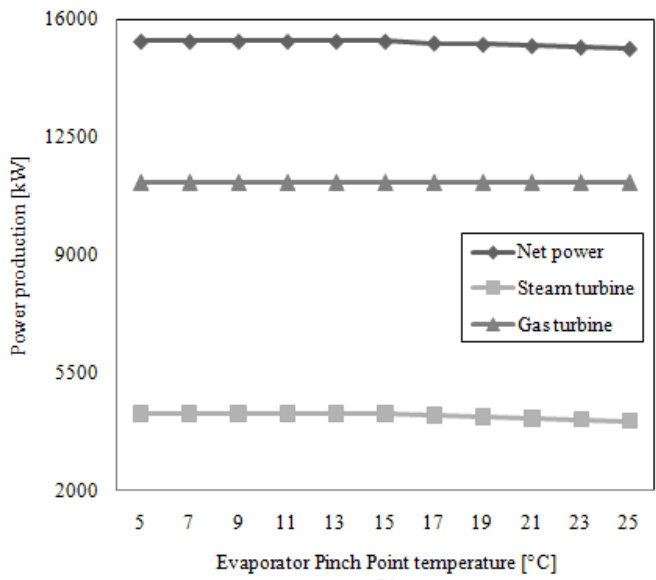

(b)

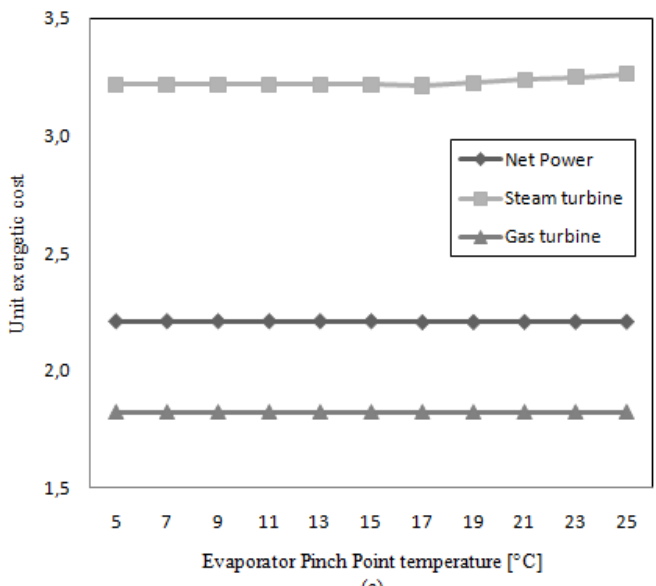

(c)

Figure 4. Impact of the increase in the pinch point temperature in (a) the heat transfer area, (b) power production and (c) unit exergetic cost.

working fluid in the boiler, raising the temperature at the steam turbine inlet, increasing the investment cost but, it is note the rise in the generated power by steam turbine and a reduction in the unit exergetic cost as more energy is removed from the exhaust gases and the thermal efficiency increase. 

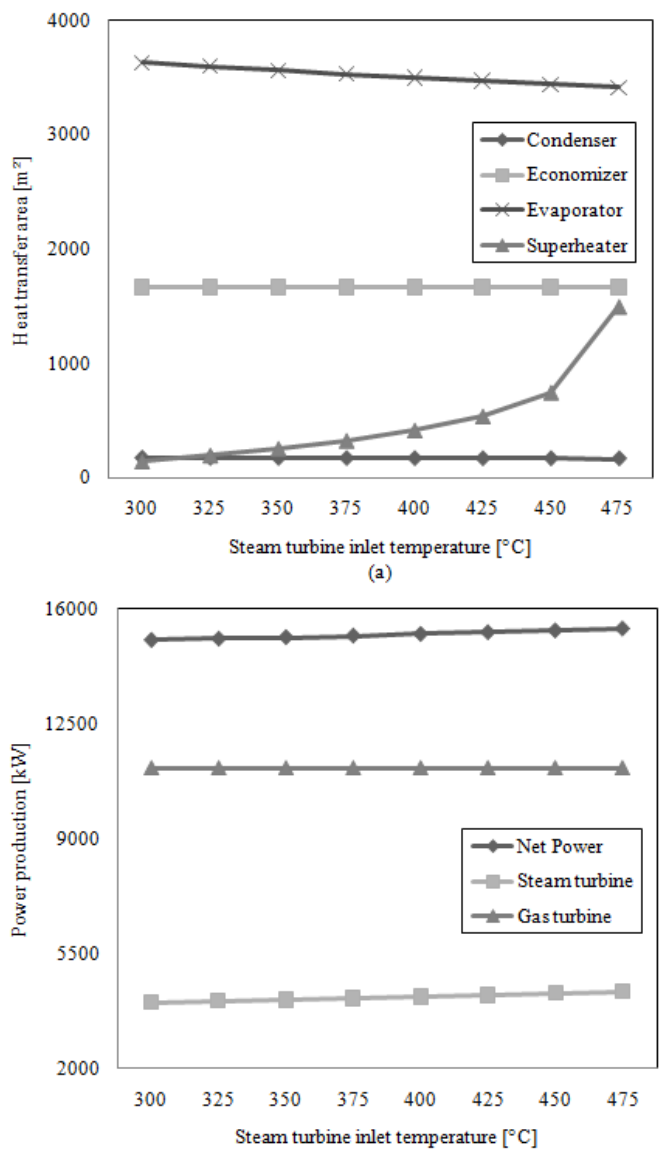

(b)

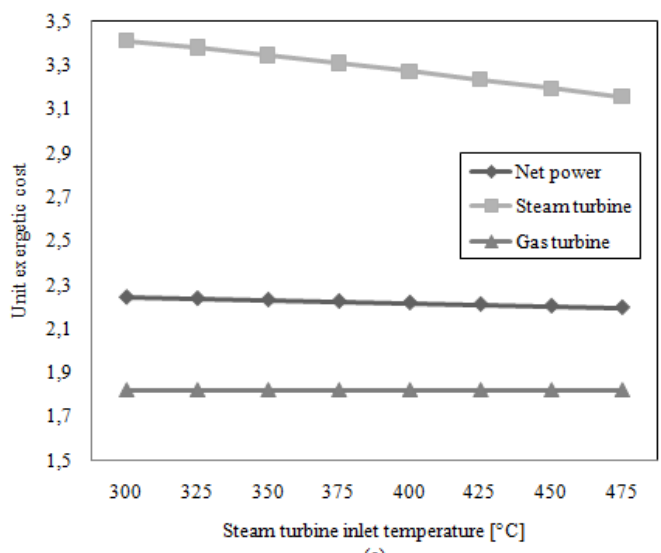

(c)

Figure 5. Impact of increase in the steam turbine inlet temperature in (a) the heat transfer area, (b) power production and (c) unit exergetic cost.

\section{CONCLUSIONS}

Based on the achieved results were able to identify the influence of five variables in the operation of the recovery cycle related to the surface heat transfer of the different components of the Rankine cycle and therefore the investment cost of the CHP combined cycle plant. It was observed that increasing the steam turbine outlet pressure produced a reduction in the condenser surface heat transfer due to a reduction in the rate of heat transfer, however, was noted a reduction in the steam turbine generated power and an increase in the unit exergetic cost, which was more evident until $7 \mathrm{kPa}$. It was also noted that the elevation of pinch point temperature substantially reduced the surface heat transfer in the
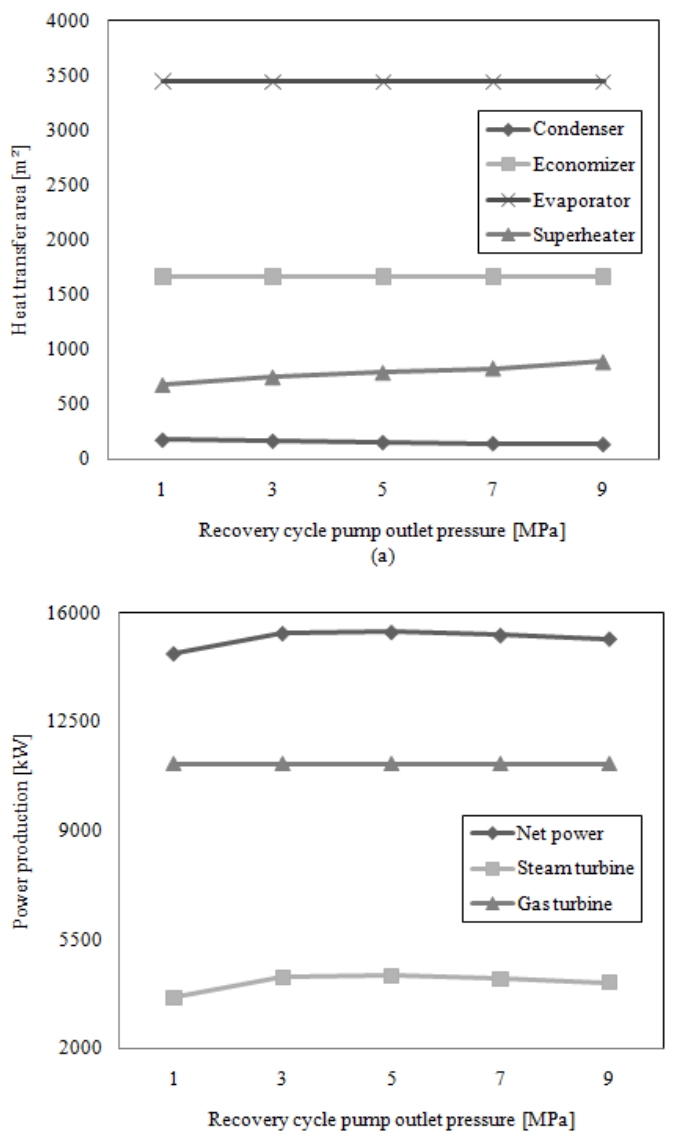

(b)

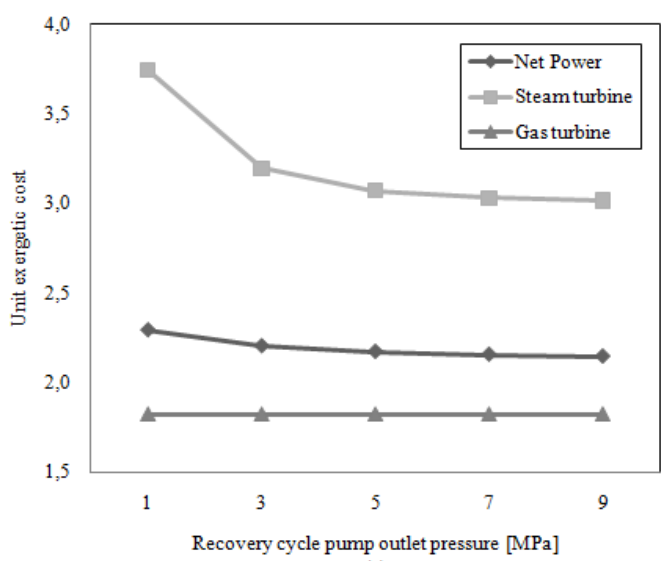

(c)

Figure 6. Impact of the increased in Rankine cycle operating pressure in (a) the heat transfer area, (b) power production and (c) unit exergetic cost. 
evaporator that happened without a significant fall in steam turbine generated or increasing the unit exergetic cost.

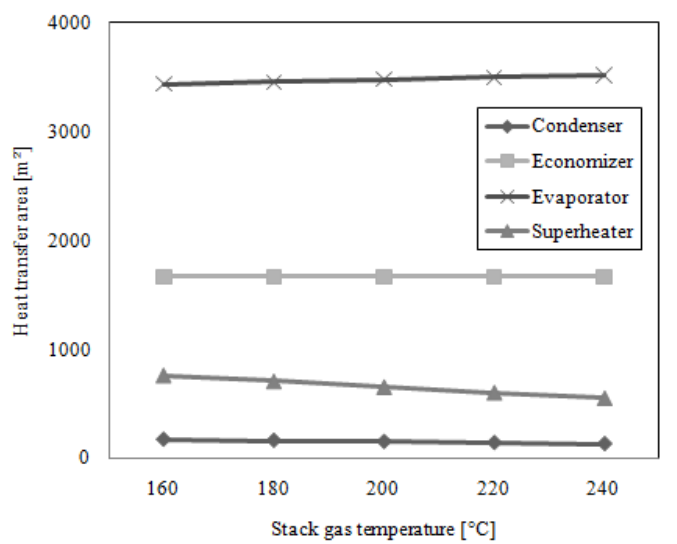

(a)

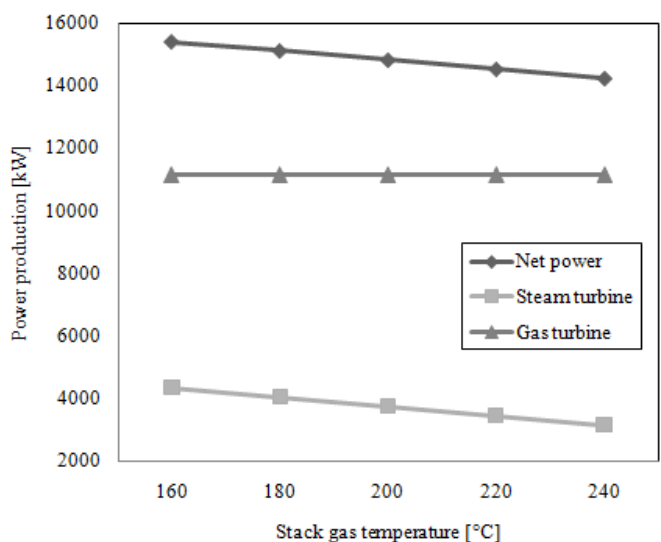

(b)

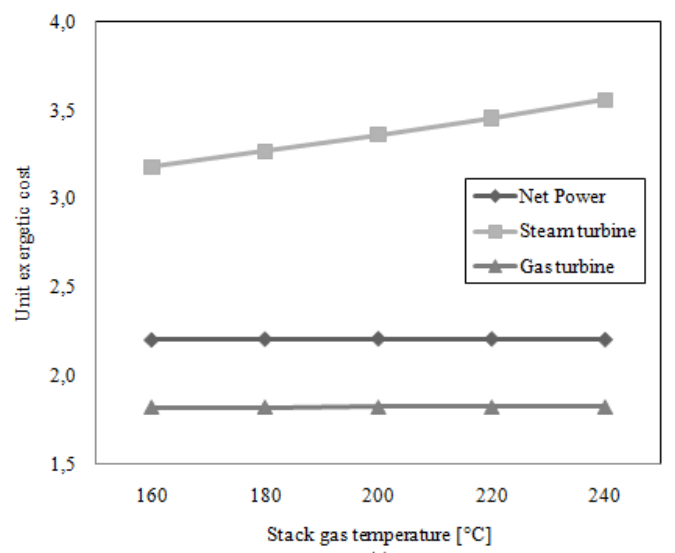

(c)

Figure 7. Impact of the increase in stack gas temperature in (a) the heat transfer area, (b) power production and (c) unit exergetic cost.

It was found that increasing the steam turbine inlet temperature rise the area required for heat transfer in the superheater, but increases the generated power in the turbine and decrease the unit exergetic cost, there are a range of values unitl 375
${ }^{\circ} \mathrm{C}$ where the growth in the area of heat transfer superheater is small. It was also noted that the increase in the Rankine cycle operating pressure produced an increase in superheater heat transfer surface and in the generated power by the steam turbine, and a reduction in the unit exergetic cost, with is a range of values until $5 \mathrm{MPa}$ for which the increase in the generated power and the reduction in the unit exergetic cost.

The reduction in the stack gas temperature for single pressure level in the recovery boiler suggest that it is necessary to increase the superheater surface of heat transfer to maintain the steam turbine inlet temperature causing an increase in the combined cycle investment cost, however the steam turbine generated power rise and the unit exergetic cost diminish.

\section{ACKNOWLEDGEMENTS}

We would like to thank the Pontifical Catholic University of Minas Gerais, Ibiritermo S/A, FAPEMIG (Foundation for Research Support of Minas Gerais) and CNPq (Nacional Council of Scientific and Tecnological Development) for the support given to the development and the elaboration of this paper and to the master degree students Ricardo Fonseca Soares and Wagner Euzébio Roberto for the support at the beginning of this work.

\section{REFERENCES}

Accadia, M. D., and Rossi, F., 1998, Thermoeconomic Optimization of a Refrigeration Plant, Int. J. Refrig., Vol. 21, No. 1, pp. 42-54.

Bolland, O., Thermal power generation. Department of Energy Process Engineering, NTNU. 2008.

Cardona, E., and Piacentino, A., 2006, A New Approach to Exergoeconomic Analysis and Design of Variable Demand Energy System, Energy Vol. 31, pp. 490-515.

Cardona, E., and Piacentino, A., 2007, Optimal Design of CHCP Plant and Civil Sector by Thermoeconomics, Applied Energy, Vol. 84, pp. 729-748.

Chemica Logic, 2011, ChemicaLogic Steam Tab Companion, Available in: $<$ http://www.chemicalogic.com/steamtab/companion/ default.htm $>$.

Erlach, B., Serra, L., and Valero, A., 1999, Structural Theory as Standard for Thermoeconomics, Energy Conversion and Management, Vol. 40, pp. 1627-1649.

Santos, J. C. S., 2006, Aplicação da Neguentropia na Modelagem Termoeconômica de Sistemas, 163 p, PhD Thesis. (in Portuguese)

Kwak, H. Y., Kim, D. J., and Jeon, J. S., 2003, Exergetic and Thermoeconomic Analyses of Power Plant, Energy, Vol. 28, pp. 343-360. 
Lozano, M. A., and Vallero A, 1986, Determinacion de la exergia para sustâncias de interes industrial, Depto de Termodinámica y Fisicoquímica, ESTII. Universidad de Zaragoza. Ingenieria química.

Misra, R. D., Sahoo, P. K., and Gupta, A., 2002, Application of the Exergetic Cost Theory to the $\mathrm{LiBr} / \mathrm{H} 2 \mathrm{O}$ Vapour Absorption System, Energy, Vol. 27, pp. 1009-1025.

Modesto, M., and Nebra, S. A., 2006, Analysis of a Repowering Proposal to the Power Generation System of a Steel Mill Plant through the Exergetic Cost Method, Energy, Vol. 31, pp. 3261-3277.

Valero, A., Serra, L., and Uche, J., 2006, Fundamentals of Exergy Cost Accounting and Thermoeconomics. Part I: Theory, Journal of Energy Resources Technology, Vol. 128, pp. 1-8.

Zhang, C., Chen S., Zheng, C., and Lou, X., 2007, Thermoeconomic Diagnosis of a Coal Fired Power Plant, Energy Conversion and Management, Vol. 48, pp. 405-419.

Zhang, C., Wang, Y., Zheng, C., and Lou, X., 2006, Exergy Cost Analysis of a Coal Fired Power Plant based on Structural Theory of Thermoeconomics, Energy Conversion and Management, Vol. 47, pp. 817-843.

Received: January 15, 2010 Revised: February 14, 2010

Accepted: March 14, 2010 